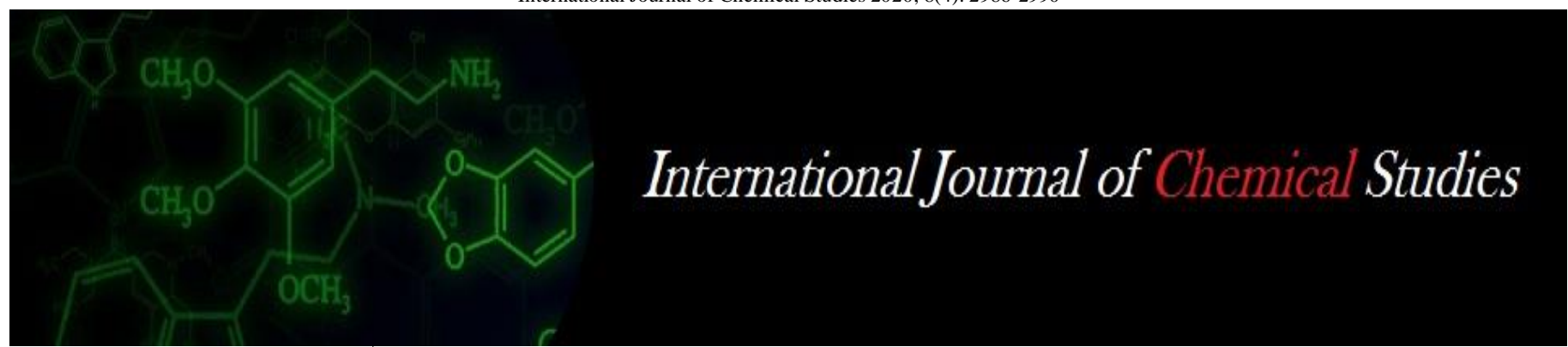

P-ISSN: 2349-8528

E-ISSN: 2321-4902

www.chemijournal.com

IJCS 2020; 8(4): 2986-2990

(C) 2020 IJCS

Received: 14-05-2020

Accepted: 16-06-2020

Subhasmita Sahu

Department of Floriculture and

Landscaping, College of

Agriculture, OUAT,

Bhubaneswar, Odisha, India

Dr. Manas Ranjan Nath

Asst. Floriculturist, AICRP,

Floriculture, OUAT,

Bhubaneswar, Odisha, India

Dr. Siddharth Kumar Palai

Floriculturist, AICRP,

Floriculture, OUAT,

Bhubaneswar, Odisha, India

Subhadarsini Pradhan

Department of Floriculture and

Landscaping, College of

Agriculture, OUAT,

Bhubaneswar, Odisha, India

Corresponding Author:

Subhasmita Sahu

Department of Floriculture and

Landscaping, College of

Agriculture, OUAT,

Bhubaneswar, Odisha, India

\section{Effect of split application of phosphorus on vegetative and reproductive growth of Gladiolus (Gladiolus grandiflorus L.) "Candyman" under Bhubaneswar condition}

\author{
Subhasmita Sahu, Dr. Manas Ranjan Nath, Dr. Siddharth Kumar Palai \\ and Subhadarsini Pradhan
}

DOI: https://doi.org/10.22271/chemi.2020.v8.i4aj.10103

\begin{abstract}
The present investigation entitled "Effect of split application of phosphorus on vegetative and reproductive growth of Gladiolus (Gladiolus grandiflorus L.) "Candyman" under Bhubaneswar condition" was conducted at College of Agriculture, OUAT, Bhubaneswar, Odisha during the period from $7^{\text {th }}$ November 2018 to $10^{\text {th }}$ April 2019. The experiment was laid out with thirteen treatment and three replications following RBD to study the effect of different doses and number of split application of phosphorus in gladiolus. The treatments include four levels of phosphorus doses $(10 \mathrm{~g}, 20 \mathrm{~g}, 30 \mathrm{~g}, 50 \mathrm{~g})$ and three levels of number of split application at 15, 30, 45 days after planting with a constant dose of $40 \mathrm{~g}$ nitrogen in two equal split at 15days and 30 days after planting and 30g. potassium after 15 days of planting and $T_{13}$ as control without any fertilizer application. The results derived from the experiment indicate that application of phosphorus exhibited significant improvements in vegetative characteristics, reproductive characteristics and production of corms and cormels. In contrast to this the control plots which are devoid of any fertilizers experienced poor vegetative growth along with inferior quality flower spike with less yield of corm and cormels. Among all the treatment treatment $\mathrm{T}_{4}(50 \mathrm{~g}$ phosphorus once at time) was shown best result with respect to vegetative parameters, including plant height, number of leaves per plant, leaf width and plant spread.andT 7 (30g phosphorus in two equal splits) was shown better reproductive growth in both quality and quantity (spike length, rachis length, spike per one square meter, number of florets per spike, flowering duration).
\end{abstract}

Keywords: Gladiolus, phosphorus, split application, growth, odisha

\section{Introduction}

Gladiolus is grown as a cut flower commercially for its in the state of Odisha as well as in India. In landscape gardening it is used for display due to its various colour. In gardens, it is generally suitable for herbaceous border, bedding, rockeries and pot culture. Among several factors having influence on growth, flowering and corm production of Gladiolus nutrients especially the primary nutrients like nitrogen, phosphorus and potassium plays a very significant role. Fertilizer requirements for rapidly growing gladiolus vary with climatic conditions, irrigation method and soil type (Wilfret, 1980) ${ }^{[12]}$. It is necessary to provide fertilizer frequently in sandy soil, especially during the rainy season.

Often phosphorus is the limiting element in soil. Primarily it is absorbed as the monovalent phosphate anion $\left(\mathrm{H}_{2} \mathrm{PO}_{4}^{-1}\right)$ by plants and then after less rapidly as the divalent anion $\left(\mathrm{H}_{2} \mathrm{PO}_{4}^{-2}\right)$. Abundance of these two ions is controlled by soil $\mathrm{pH}$. Acidic $\mathrm{pH}$ favours abundance of $\mathrm{H}_{2} \mathrm{PO}_{4}{ }^{-}$ ${ }^{1}$ where as $\mathrm{pH}$ above 7 favours the $\mathrm{H}_{2} \mathrm{PO}_{4}{ }^{-2}$ ion. Phosphorus deficient plants have stunted growth and in contrast to nitrogen deficient, are often found dark green in colour. Maturity is often delayed compared to plants containing abundant phosphorus. Phosphorus is an important constituent of many sugar phosphates involved in photosynthesis, respiration and other metabolic processes and it is also part of nucleotides and the phospholipids present in the membrane. Being a part of ATP, ADP, AMP and pyrophosphate (PPi) It also plays an essential role in energy metabolism, (Salisbury and Ross, 1992) ${ }^{[11]}$. Phosphorus deficiency also responsible in a loss in cell integrity (Ratnayake et al., 1978) ${ }^{[10]}$. Phosphorus has 
significant effect in growth of gladiolus and it is observed that phosphorus caused the tallest plants. Phosphorus also increases number of leaves /clump (Pandey et al., 2000) ${ }^{[9]}$.

Gladiolus being excellent cut flower of long shelflife gaining popularity in capital city of Odisha like, Bhubaneswar, for decoration of co-operative meeting halls, parties, office tables However studies about requirement of phosphorus and application frequency for better utilization by plants to achieve the higher yield in field condition are limited and detailed information regarding these are inadequate.

Keeping these view, to conduct an experiment on " Effect of split application of phosphorus on vegetative and reproductive growth of Gladiolus (Gladiolus Grandiflorus L.)

"Candyman" under Bhubaneswar condition." in was found to be worthwhile.

\section{Material methods}

The present experiment was undertaken in the form of field experiment in open condition in front of the administrative block at College of Agriculture, Odisha University of Agriculture and Technology, Bhubaneswar during the year 2018-2019. The experiment site is situated inside the college campus of College of Agriculture, Odisha University of Agriculture and Technology, Siripur, Bhubaneswar. This capital city of Odisha is situated $63 \mathrm{~km}$ away from Bay of Bengal, at an altitude of $25.5 \mathrm{~m}$. above the mean sea level. Geographically location of Bhubaneswar is at $20^{\circ} 15^{\prime}$ North latitude and $85^{\circ} 15^{\prime}$ East longitude. In Bhubaneswar condition sub tropical climate is experienced. The mean annual precipitation of Bhubaneswar is $1522 \mathrm{~mm}$ out of which 1293 $\mathrm{mm}$ is received within June to Septmber during the onset of mosoon and the rest $229 \mathrm{~mm}$ is received during October to May. The average maximum temperature ranges of $35^{\circ} \mathrm{C}$ to $40^{\circ} \mathrm{C}$ in summer particularly during May and June and in winter the minimum temperature fluctuate in between $13^{\circ} \mathrm{C}$ to $15^{\circ} \mathrm{C}$ during the month of December and January. The relative humidity varies between $50 \%$ in summer and $90 \%$ in the rainy season. The corms of gladiolus were brought form Govt. Nursey of Kalyani BCKV, West Bengal under AICRP on Floriculture, OUAT, Bhubaneswar. Candiman is exotic variety of gladiolus. It is locally known as Rani.

The experiment was conducted at College of Agriculture, OUAT, Bhubaneswar, Odisha during the period from $7^{\text {th }}$ November 2018 to $10^{\text {th }}$ April 2019. The experiment was laid with 12 treatments and one control treatment (without any fertilizer application) and three replication in RBD. The details of the treatments are $\mathrm{T}_{1}\left(10 \mathrm{~g}\right.$ phosphorus $/ \mathrm{m}^{2}, \mathrm{~T}_{2}-20 \mathrm{~g}$ phosphorus $\left./ \mathrm{m}^{2}\right), \mathrm{T}_{3}$ (30 g phosphorus $/ \mathrm{m}^{2}$ once), $\mathrm{T}_{4}$ (50 g phosphorus $/ \mathrm{m}^{2}$ once), $\mathrm{T}_{5}$ (10 g phosphorus $/ \mathrm{m}^{2}$ in 2 splits at fortnight interval), $\mathrm{T}_{6}\left(20 \mathrm{~g}\right.$ phosphorus $/ \mathrm{m}^{2}$ in 2 splits at fortnight interval, $\mathrm{T}_{7-} 30 \mathrm{~g}$ phosphorus $/ \mathrm{m}^{2}$ in 2 splits at fortnight interval $), \mathrm{T}_{8}\left(50 \mathrm{~g}\right.$ phosphorus $/ \mathrm{m}^{2}$ in 2 splits at fortnight interval $), \mathrm{T}_{9}\left(10 \mathrm{~g}\right.$ phosphorus $/ \mathrm{m}^{2}$ in 3 splits at fortnight interval), $\mathrm{T}_{10}\left(20 \mathrm{~g}\right.$ phosphorus $/ \mathrm{m}^{2}$ in 3 splits at fortnight interval), $T_{11}\left(30 \mathrm{~g}\right.$ phosphorus $/ \mathrm{m}^{2}$ in 3 splits at fortnight interval), $\mathrm{T}_{12}\left(50 \mathrm{~g}\right.$ phosphorus $/ \mathrm{m}^{2}$ in 3 splits at fortnight interval), $\mathrm{T}_{13}$ (control -No fertilizer application). The whole experimental area comprised of 39 plots of $1 \mathrm{~m}^{2}$. The gladiolus bulbs are planted with $30 \times 25 \mathrm{~cm}^{2}$ with a depth of $5-7 \mathrm{~cm}$ depth. Besides phosphorus standard dose of nitrogen and potassium was given. All three nutrients were applied from straight fertilizers urea $(46 \% \mathrm{~N})$, single superphosphate $\left(16 \% \mathrm{P}_{2} \mathrm{O}_{5}\right)$, muriate of potash $\left(60 \% \mathrm{~K}_{2} \mathrm{O}_{5}\right) .40 \mathrm{~g}$ of nitrogen in two splits at fortnight interval and $30 \mathrm{~g}$ of potassium once after 15days of planting was given in each plot except control. Rest half of the nitrogen was given 15 days after first application. For recording various biometric observations, three plants under each treatment and replication were selected at random. The selected plants were labelled properly with steal labels. The data recorded on five plants for various parameters were averaged and the mean values were used for statistical analysis.

\section{Statistical analysis}

Analysis of variance of different variables was carried out to know the degree of variation among all the treatments. The data obtained from various characters under study were analyzed by the method of analysis of variance as described by Gomez and Gomez (1984) ${ }^{[4]}$.

\section{Result and discussion effect of split dose of phosphorus on vegetative growth of gladiolus (Gladiolus grandifloras $\mathbf{L}$.) "Candyman"}

It has been observed that application of phosphorus gives better results on vegetative parameters and increased significantly over control. Phosphorus is essesntial for cell division and fat and albumin production and hence it directly improves the vegetative characters like plant height, number of leaves, leaf width and plant spread. Phosphorus being involved in development of lateral fibrous rootlets also help in intake of other nutrients and help in growth and development of plant. Various studies on this aspects revealed that phosphorus application significantly influenced the vegetative characters as reported by Pandey et al. (2000) ${ }^{[9]}$, Baweja et al. (2001) ${ }^{[1]}$, Haokip and Singh (2005) ${ }^{[6]}$ and Chandana and Dorajeerao (2014) ${ }^{[7]}$.

Plant height varied significantly among the different treatments and maximum plant height $89.22 \mathrm{~cm}$ was recorded in treatment $\mathrm{T}_{4}$ (50 gram phosphorus applied once). Minimum plant height was recorded in control i.e. $72.00 \mathrm{~cm}$. The highest plant height observed due to application higher doses of phosphorus as reported by Pandey et al. that phosphorus has significant effect in growth of gladiolus and phosphorus caused the tallest plant and also supported by Baweja et al. $(2001)^{[1]}$ that phosphorus caused significant increase in plant height.

Among all the treatment maximum number of leaves per plant was recorded in treatment $\mathrm{T}_{4}$ (50 gram phosphorus applied once) i.e. 9.44 followed by $\mathrm{T}_{8}$ ( 50 gram phosphorus in 2 split doses at fortnight interval) i.e. 8.88 which are statistically at par. Minimum leaves per plant was recorded in control (7.44). This result was also supported by Pandey et al. (2000) ${ }^{[9]}$ and Chandana and Dorajeerao (2014) ${ }^{[7]}$.

The leaf width varied significantly among different doses and number of split application phosphorus. Leaf width was significant increased by fertilizer application over control. Among all the treatments maximum leaf width $(3.24 \mathrm{~cm})$ was recorded in treatment $\mathrm{T}_{4}$ (50 gram phosphorus once). Minimum leaf width was recorded in control plot $(2.53 \mathrm{~cm})$. The result was well supported by Haokip and Singh $(2005)^{[6]}$ that application of phosphorus increases leaf area hence also the leaf width and was well supported by Chandana and Dorajeerao (2014) ${ }^{[7]}$

Among all the treatment maximum plant spread was recorded in treatment $\mathrm{T}_{8}$ (50 gram phosphorus in 2 split doses at fortnight interval) i.e. $31.83 \mathrm{~cm}$ and second highest plant spread $(30.33 \mathrm{~cm})$ was recorded in treatment $\mathrm{T}_{4}(50$ gram phosphorus once) which is statistically at par with $\mathrm{T}_{8}$. Minimum plant $(24.33 \mathrm{~cm}$.) spread was recorded in control. This result was suppoetrd by Chandana and Dorajeerao, 2014 [7] that phosphorus influenced vegetative parameters and growth parameters like crop growth rate and net assimilation rate. 
Table 1: Effect of split dose of phosphorus on vegetative growth of gladiolus (Gladiolus grandifloras L.) "Candyman"

\begin{tabular}{|c|c|c|c|c|}
\hline Treatments & Plant height $(\mathbf{c m})$ & Number of leaves per plant & Leaf width(cm) & Plant spread in N-Sdirection (cm) \\
\hline $\mathrm{T}_{1}$ & 77.92 & 8.33 & 2.89 & 25.55 \\
\hline $\mathrm{T}_{2}$ & 79.66 & 7.55 & 2.88 & 27.66 \\
\hline $\mathrm{T}_{3}$ & 77.11 & 8.44 & 3.00 & 29.03 \\
\hline $\mathrm{T}_{4}$ & 89.22 & 9.44 & 3.24 & 28.33 \\
\hline $\mathrm{T}_{5}$ & 72.64 & 8.44 & 2.80 & 28.66 \\
\hline $\mathrm{T}_{6}$ & 79.22 & 8.10 & 2.87 & 28.90 \\
\hline $\mathrm{T}_{7}$ & 77.66 & 8.00 & 2.95 & 31.83 \\
\hline $\mathrm{T}_{8}$ & 78.55 & 8.88 & 2.98 & 28.33 \\
\hline $\mathrm{T}_{9}$ & 73.22 & 7.66 & 2.68 & 28.55 \\
\hline $\mathrm{T}_{10}$ & 80.33 & 8.55 & 2.82 & 28.17 \\
\hline $\mathrm{T}_{11}$ & 76.32 & 8.55 & 2.88 & 27.77 \\
\hline $\mathrm{T}_{12}$ & 76.99 & 8.33 & 2.96 & 24.33 \\
\hline Control & 72.00 & 7.44 & 2.53 & 2.66 \\
\hline C.D. & 7.53 & 0.86 & 0.24 & 0.90 \\
\hline SE(m) & 2.56 & 0.29 & 0.08 & \\
\hline
\end{tabular}

Significant at $5 \%$

\section{Effect of split dose of phosphorus on reproductive growth of gladiolus (Gladiolus grandifloras L.) "Candyman"}

From the result, it can be observed that reproductive characteristics of gladiolus was significantly influenced by application of different doses of phosphorus and their of split application as phosphorus important for flowering, fruiting including seed formation. The result shows application of phosphorus in higher levels improved the quality of flower which is well supported by Bhattacharjee (1981) ${ }^{[2]}$. The result was also well supported by Gowda, Jayanthi and Raju (1988) ${ }^{[5]}$, Baweja et al. (2001) ${ }^{[1]}$, Mishra (2004) ${ }^{[8]}$

Maximum spike length was recorded in treatment $\mathrm{T}_{11}$ (30gram phosphorus in 3 split at fortnightly interval) i.e. $147.60 \mathrm{~cm}$. followed by treatment $\mathrm{T}_{7}$ (30gram phosphorus in 2 split at fortnightly interval) i.e. $136.33 \mathrm{~cm}$ which is statistically at par with $\mathrm{T}_{11}$. Minimum spike length was recorded in control $(121.66 \mathrm{~cm})$. The same result was also found by Mishra (2004) ${ }^{[8]}$ that $30 \mathrm{~g}$ phosphorus per 1 square meter gives maximum spike length and significant increase occurs due to phosphorus application which was supported by Baweja et al., 2001 [1] and also supported by Gowda, Jayanthi and Raju (1988) ${ }^{[5]}$ that higher dose of phosphorus gave better result.

Maximum rachis length was recorded in treatment $\mathrm{T}_{7}$ (30gram phosphorus in 2 split at fortnightly interval) i.e. $58.10 \mathrm{~cm}$. followed by treatment $T_{11}$ (30gram phosphorus in 3 split at fortnightly interval) i.e. $55.44 \mathrm{~cm}$ which is statistically at par with $\mathrm{T}_{7}$. Minimum rachis length was recorded in control plot $(45.33 \mathrm{~cm})$. This result was supported by Baweja et al., 2001 ${ }^{[1]}$ and Gowda, Jayanthi and Raju (1988) ${ }^{[5]}$

Maximum flower diameter of second floret $(12.33 \mathrm{~cm})$ was recorded in treatment $T_{3}$ (30 gram phosphorus applied once) and minimum diameter of second floret was recorded in control i.e. $10.13 \mathrm{~cm}$. There is a significant difference in flower diameter among different doses and split application of phosphorus which was well supported by Baweja et al., 2001 ${ }^{[1]}$ and Gowda, Jayanthi and Raju (1988) ${ }^{[5]}$

The number of florets per spike was recorded maximum in treatment $\mathrm{T}_{7}$ (30gram phosphorus in 2 split at fortnightly interval) i.e. 15.11 florets per spike and followed by treatment $\mathrm{T}_{3}$ (30 gram phosphorus applied once) i.e. 13.77 florets per spike which is statistically at par with treatment $T_{7}$. Minimum number of floret (10.33) was recorded in control. The result was well supported by Baweja et al., $2001^{[1]}$ and Chauhan et al., $2014^{[3]}$.
Maximum number of spike per $\mathrm{m}^{2}$ was recorded in treatment $\mathrm{T}_{7}$ (30gram phosphorus in 2 split at fortnightly interval) i.e. 15.66 and minimum number of spike per $\mathrm{m}^{2}$ (11.33) was recorded in control plot. The similar result was found by Gowda, Jayanthi and Raju (1988) ${ }^{[5]}$

The spike circumference varied significantly among different doses and number of split application of phosphorus. Circumference of spike was significantly increased over control by application phosphorus. Maximum spike circumference $(3.2 \mathrm{~cm})$ was recorded in treatment $\mathrm{T}_{11}$ (30gram phosphorus in 3 split at fortnightly interval) followed by $\mathrm{T}_{3}$ (30 gram phosphorus applied once) i.e. $3.02 \mathrm{~cm}$ which is statistically at par with $\mathrm{T}_{11}$ (30gram phosphorus in 3 split at fortnightly interval). Minimum spike circumference $(2.40 \mathrm{~cm})$ was recorded in control.

The fresh weight of spike varied significantly among different doses and number of split application of phosphorus. Fresh weight of spike was significantly increased by fertilizer application over control. Maximum fresh weight of spike $(140 \mathrm{gm})$ was recorded in treatment $\mathrm{T}_{11}$ (30gram phosphorus in 3 split at fortnightly interval) followed by $\mathrm{T}_{3}$ (30 gram phosphorus applied once) i.e. 128gram which is statistically at par with $\mathrm{T}_{11}$ (30gram phosphorus in 3 split at fortnightly interval). Maximum spike length and maximum spike circumference also caused maximum fresh weight of spike. Therefore this result also well supported by Mishra, $(2004)^{[8]}$. Maximum flowering duration of 15 days was recorded in both $\mathrm{T}_{11}$ (30gram phosphorus in 3 split at fortnightly interval) and $\mathrm{T}_{3}$ (30 gram phosphorus applied once) and then followed by treatment $\mathrm{T}_{7}$ (30gram phosphorus in 2 split at fortnightly interval) i.e. 14days which is statistically at par with $\mathrm{T}_{11}$ and $\mathrm{T}_{3}$ and minimum duration of flowering (10days) found in control. This result was well supported by Mishra, (2004) ${ }^{[8]}$.

The vaselife of gladiolus varied significantly among different doses and number of split application of phosphorus. Circumference of spike of was significantly increased over control by application phosphorus. Maximum vase life (7days 12 hours) was recorded in treatment $\mathrm{T}_{11}$ (30gram phosphorus in 3 split at fortnightly interval). Minimum vase life (4days 16 hours) was recorded in control plot which was well supported by Chouhan et al. (2014) ${ }^{[3]}$ 
Table 2: Effect of split dose of phosphorus on reproductive growth of gladiolus (Gladiolus grandifloras L.) "Candyman"

\begin{tabular}{|c|c|c|c|c|c|}
\hline Treatments & $\begin{array}{l}\text { Spike length } \\
(\mathrm{cm})\end{array}$ & $\begin{array}{c}\text { Rachis length } \\
(\mathrm{cm})\end{array}$ & $\begin{array}{c}\begin{array}{c}\text { Flower diameter of second floret } \\
(\mathrm{cm})\end{array} \\
\end{array}$ & $\begin{array}{c}\begin{array}{c}\text { Number of florets per } \\
\text { spike }\end{array} \\
\end{array}$ & $\begin{array}{c}\begin{array}{c}\text { Number of spike per } \\
\mathbf{m}^{2}\end{array} \\
\end{array}$ \\
\hline $\mathrm{T}_{1}$ & 129.78 & 51.33 & 11.03 & 13.11 & 12.66 \\
\hline $\mathrm{T}_{2}$ & 124.66 & 47.66 & 11.14 & 13.22 & 12.66 \\
\hline $\mathrm{T}_{3}$ & 128.89 & 48.16 & 12.33 & 13.77 & 13.66 \\
\hline $\mathrm{T}_{4}$ & 130.22 & 47.91 & 11.18 & 12.11 & 12.33 \\
\hline $\mathrm{T}_{5}$ & 132.05 & 51.43 & 11.15 & 12.66 & 12.33 \\
\hline $\mathrm{T}_{6}$ & 135.00 & 49.80 & 11.27 & 12.77 & 13.66 \\
\hline $\mathrm{T}_{7}$ & 136.33 & 58.10 & 10.80 & 15.11 & 15.66 \\
\hline $\mathrm{T}_{8}$ & 135.11 & 51.54 & 10.83 & 13.11 & 11.33 \\
\hline $\mathrm{T}_{9}$ & 131.33 & 49.55 & 11.13 & 13.00 & 12.00 \\
\hline $\mathrm{T}_{10}$ & 133.49 & 51.33 & 11.25 & 13.11 & 11.66 \\
\hline $\mathrm{T}_{11}$ & 147.60 & 55.44 & 11.28 & 13.22 & 12.00 \\
\hline $\mathrm{T}_{12}$ & 132.11 & 51.33 & 11.20 & 13.11 & 12.33 \\
\hline Control & 121.66 & 45.33 & 10.13 & 10.33 & 11.33 \\
\hline C.D. & 12.30 & 6.07 & 0.93 & 1.65 & 2.10 \\
\hline $\mathrm{SE}(\mathrm{m})$ & 4.19 & 2.06 & 0.31 & 0.56 & 0.71 \\
\hline
\end{tabular}

Significant at $5 \%$

Table 3: Effect of split dose of phosphorus on reproductive growth of gladiolus (Gladiolus grandifloras L.) "Candyman"

\begin{tabular}{|c|c|c|c|c|}
\hline Treatments & Spike circumference $(\mathrm{cm})$ & Fresh weight of Spike(g) & Flowering duration & Vaselife \\
\hline $\mathrm{T}_{1}$ & 2.67 & 120.00 & 11days16 hours & 4days 18hours \\
\hline $\mathrm{T}_{2}$ & 2.83 & 123.33 & 12days16hours & 5days 20hours \\
\hline $\mathrm{T}_{3}$ & 3.02 & 128.33 & 15days & 5.18hours \\
\hline $\mathrm{T}_{4}$ & 2.78 & 118.33 & 11days & 5days 12hours \\
\hline $\mathrm{T}_{5}$ & 2.65 & 112.33 & 10days16hours & 4days 17hours \\
\hline $\mathrm{T}_{6}$ & 2.82 & 100.667 & 11days 8hours & 4days14hours \\
\hline $\mathrm{T}_{7}$ & 2.84 & 108.33 & 14days & 5days \\
\hline $\mathrm{T}_{8}$ & 2.71 & 101.67 & 11days 8hours & 5days 12 hours \\
\hline $\mathrm{T}_{9}$ & 2.73 & 98.33 & 11days 16hours & 5days 4hours \\
\hline $\mathrm{T}_{10}$ & 2.74 & 91.67 & 11days16hours & 4days 16hours \\
\hline $\mathrm{T}_{11}$ & 3.20 & 140.00 & 15days & 7days 12hours \\
\hline $\mathrm{T}_{12}$ & 2.83 & 88.33 & 11days 8hours & 5days 23hours \\
\hline Control & 2.40 & 138.33 & 10days & 4days 16 hours \\
\hline C.D. & 0.34 & 15.35 & 2.00 & 1.42 \\
\hline $\mathrm{SE}(\mathrm{m})$ & 0.11 & 5.22 & 0.68 & 0.48 \\
\hline
\end{tabular}

Significant at $5 \%$

\section{Conclusion}

From the result and discussion it can be summerized that application of $50 \mathrm{~g}$. once at a time produced better vegetative growth (plant height, number of leaves per plant, width of leaves, plant spread) and From commercial point of view longer spike and rachis and more number of spike per one square meter per plant have great importance and all these characters combinely observed with application $30 \mathrm{~g}$. phosphorus in two equal splits at 15 days interval. So we can recommend to apply $30 \mathrm{~g}$. phosphorus in two equal splits at 15 days interval for cultivation of gladiolus in Bhubaneswar condition.

\section{Acknowledgement}

I am very much thankful to my M.Sc. guide Dr. Manas Ranjan Nath for his ever willing help in preparation of this manuscript. I am also grateful to Dr. (Mrs.) Sashikala Beura, Dr. Siddarth Kumar Palai, Dr. Narayan Panda for their help and guidance during the period of investigation.

\section{References}

1. Baweja HS, Kashyap AS, Panwar AS, Shulka YR. Response of gladiolus to nitrogen and phosphorus under the mid-hill conditions of HP, Himalayas Indian Journal of Hill Farming. 2001; 14:88-91.

2. Bhattacharjee SK. Influence of nitrogen, phosphorus and potash fertilization on flowering and corm production in gladiolus. Singapore Jr. of Primary Industries. 1981; 9(1):23-27.

3. Chouhan P, Vidhya SM, Vijay R. Effect of NPK on Physico-Chemical Parameters of Gladiolus (Gladiolus hybridus Hort.) Cv. White Prosperity. Int J Sci Res Publications. 2014; 4:50-53.

4. Gomez KA, Gomez AA. Statistical procedure for Agricultural research. Second Edition, Wiley publication, 1984.

5. Gowda JVN, Jayanthi R, Raju B. Studies on effect of nitrogen and phosphorus on flowering in gladiolus cv. Debonair. Current Research Univ. It Agril Sciences, Banglore. 1988; 17(6).

6. Haokip N, Singh UC. Response of nitrogen and phosphorus on growth and flowering parameters in gladiolus. J. Orn. Hort. 2005; 8(4):314-315.

7. Chandana K, Dorajeerao AVD. Effect of graded levels of nitrogen and phosphorus on growth and yield of gladiolus (Gladiolus grandiflourus L.) cv. White Prosperity in coastal A.P., India. Plant Archives. 2014; 14(1):143-150.

8. Mishra HP. Response of gladiolus to different levels of nitrogen and phosphorus on growth, spike and corm production in calcareous soil. Ind. J. Hort. 2004; 61(2):168-170.

9. Pandey RK, Rathore P, Singh MK. Effect of different levels of phosphorus and nitrogen on gladiolus under Agra conditions. J. Orn. Hort. 2000; 3(1):60-61. 
10. Ratnayake M, Leonard RT, Menge JA. Root exudation in relation to supply of phosphorus and its possible relevance to mycorrhizal formation, New Phytol. 1978; 81:543-552.

11. Salisburey FB, Ross CW. Mineral nutrition. In plant physiology. Wadsworth Pub. Co. Belmont, California. 1992; 4:116-135.

12. Wilfret GJ. Introduction to floriculture (Larson, R.A. ed.). Academic Press, Inc. New York, 1980, 165-181. 